\title{
Linking supervisor incivility with job embed- dedness and cynicism: The mediating role of employee self-efficacy
}

\author{
Uju Violet Alola, ${ }^{1 *}$ Simplice Asongur, Andrew Adewale Alola ${ }^{1}$ \\ ${ }^{1}$ Istanbul Gelisim University, Istanbul Turkey. South Ural State University, Russian Federation \\ ${ }^{2}$ African Governance and Development Institute, Cameroon
}

\begin{abstract}
Applying the conservation of resource resources theory and the self-efficacy theory, this study investigates the relationship between supervisor incivility, self-efficacy, cynicism and the job embeddedness of employees in the hotel industry. The role of self-efficacy, as an important variable that mediates the relationship between the predictor and the criterion variable, is significantly evaluated. A non-probability sampling technique was used to collect 245 questionnaires from frontline employees of five and four-star hotels in Nigeria. The findings reveal that supervisor incivility has a negative effect on self-efficacy and a positive effect on cynicism, and that self-efficacy negatively affects cynicism. There was no significant relationship with job embeddedness in the study. Importantly, the investigation establishes that self-efficacy is a mediating variable between supervisor incivility and cynicism. The study noted the importance of adopting a policy that introduces periodic seminars and professional training for both employees and supervisors, as a means for curbing incivility and cynicism. The study concludes with theoretical and practical implications, leaving room for further investigation.
\end{abstract}

Keywords: supervisor incivility; cynicism; self-efficacy; job embeddedness; Nigeria.

JEL Classification: D23; E71 ; M12; O55 


\section{Introduction}

Workplace incivility is a challenging issue for both employees and management at every level of an organization. The quest to mitigate uncivil behavior and the effect it has on employees, is on the increase according to company managers, practitioners and researchers. There is no doubt that incivility is a global issue that encompasses all fields of endeavor and is apparent in many countries, inter alia, in: the Philippines (Scott et al., 2013), Australia (Kirk et al., 2011), Singapore (Lim and Lee, 2011), India (Yeung and Griffin, 2008), New Zealand (Griffin, 2010), Nigeria (Alola et al., 2018; Alola and Alola, 2018; Alola et al., 2019) and China (Chen et al., 2013). A country's tourism sector, as well as its hotel industry, contributes significantly to the growth and development of its economy (for instance, see Alola and Alola, 2018; Akadiri et al., 2017). Incivility is, therefore, a practical/policy syndrome that demands urgent attention from management. Researchers have noted that increasing work demands, the quest to outperform others, the need to improve efficiency and constraints in meeting targets give rise to uncivil behavior. According to Anderson and Pearson (1999), incivility is a rude, insensitive, deviant behavior, targeted toward another person in order to deliberately cause harm. As such, job dissatisfaction has been proven to negatively affect employees' physical health (Lim et al., 2008) and organizational commitment (Porath and Pearson, 2010). As evident in the study of Abubakar and Arasli (2016), an employee's longevity in an organization is contingent on the mercy of his/her supervisor, and the absence of a mutual relationship leaves room for cynical behavior (Erdogan, 2002). Deducing from the arguments of Fox and Spector (1999), employees may exhibit counter productive behavioral responses when go- ing through stressful events (e.g., failing to achieve personal and organizational goals). Supervisor incivility is a very sensitive issue for an organization, because of the supposed employee-supervisor relationship. When the employee-supervisor relationship is not moving smoothly, employee has a tendency to employ cynical behavior. Also, Riasat and Nisar (2016), in their study on workplace incivility and job stress, and the work of Mahfooz, et al (2017) unanimously agreed that workplace incivility has a negative effect on employees. As opined by Anderson (1996), cynicism is characterized by distrust, frustration, reduces employee's organizational commitment towards his/her working environment. When an employee loses hope and trust in the organization, the employee becomes less committed, therefore, the tendency to display certain deviant behavior becomes evident. This is worrisome for the organization because of its adverse effect on organizational productivity and organizational sustainability (Aslan and Eren, 2014; Alola et al. 2018; Alola et al., 2018). Most often, employees tend to use cynical behavior as a defensive weapon against their supervisors' uncivil behavior. Although an employee's self-efficacy could be a core self-evaluation of his/her self-worth, the positive influence of personal attributes contradicts the assessment of an employee's negative behavior. Self-efficacy also helps employees to reduce deviant organizational behavior that violates the organization's norms and mission (Robinson and Bennett, 1995). It is relevant to note that individuals with high-efficacy might be less active in responding to negative organizational stress or supervisor incivility. Self-efficacy enables employees to handle situations, control environmental factors and complete their given tasks amidst diverse organizational stressors. Some recent scholars 
have examined the relationship between incivility and other variables, for instance; Kim and Beehr (2017) examined self-efficacy and psychological ownership on both good and bad employee behavior; Fallatah et al. (2017) on authentic leadership, self-efficacy and the turnover intention of new graduate nurses in Canada. Additionally, most employees are committed to their organizations. Nevertheless, organizations try to keep employees in their organizations (Yirik and Ekic, 2014; Karatepe and Nkendong, 2014) because they are skillful and training a new employee is more expensive than retaining a trained and experienced one.

Job embeddedness is a collection of several forces that keeps employees in their organization. According to Lee et al. (2016), employees that are embedded in an organization have less intention to quit. Organizations look out for employees who are embedded in the organization because they stay longer with that organization and can be of great benefit to the organization. Employee retention is beneficial to an organization because of the high cost associated with employee turnover. Also, it is linked with several variables in the organization, job embeddedness with the organizational outcome (Hussain and Deery, 2018), nevertheless, there is little or no evidence linking job embeddedness with self-efficacy and cynicism.

This study makes three specific contributions to the existing literature. Firstly, the study presents an empirical and theoretical account of the effect of supervisor incivility on employees' health, work outcome and performance. The study is novel because no existing literature relates supervisor incivility with job embeddedness (for instance, see Abubakar et al 2016; Kim and Beehr, 2017). Connecting the structure between supervisor incivility, job embeddedness and cynicism is essential for both theory development and building/establishing other necessary interventions for the study. Secondly, the study will depart from the existing strand of literature by testing the direct effect of supervisor incivility on cynicism and job embeddedness. This improves the scholarly understanding of the relationships between the variables without the mediating variable. Thirdly, whereas the extant literature has focused on the nexus between incivility and organizational outcomes (Hur et al., 2015), this study steers clear of the extant literature by articulating the mediating effect of self-efficacy on supervisor incivility, job embeddedness, and cynicism. Notable studies extend the strand of literature by focusing on, inter alia: emotional exhaustion (Hur et al., 2016), job performance (Nelson et al., 2017; Sharma and Singh, 2016), job satisfaction and turnover intention (Lim et al., 2016; Alola et al., 2018). Employee positive self-efficacy is widely acknowledged; the study tested the mediating effect of employee self-efficacy, which might have an effect employee. If this happens to be the case, developing employee positive self-efficacy is compelling and timely for and in the hotel industry.

The rest of the study is structured as follows. Section 2 discusses the theoretical framework and testable hypotheses in the light of the extant literature. The research methodology is covered in Section 3, while Section 4 discusses the empirical results and corresponding implications. We conclude in Section 5 with future research directions.

\section{The Theoretical Framework, Literature, and Testable Hy- potheses}




\section{Theoretical Framework}

The Conservation of Resources (COR) theory (Hobfoll, 1989), provides the foundation for the present study. At the heart of the COR theory is the notion that employees accumulate, protect, and allocate valued resources in response to environmental changes (Hobfoll and Freedy, 1993). Importantly, as resources are depleted, adverse outcomes ensue. Conversely, as resources are accumulated and protected, positive outcomes are more feasibly realized. Although the COR theory is conceived to be a general motivation theory (Hobfoll, 1989), where accumulation, protection, and the allocation of resources act to energize, direct and sustain employee behavior. This theory has often been applied to stress (Halbesleben, 2006; Harvey et al., 2007; Halbesleben et al., 2014); it has also been applied to the exchange-based relationships found in an organizational context (e.g, Perrwe et al., 2004; Treadway et al., 2005; Wright and Cropanzano, 1998). In the view of Pizam (2008), in the hospitality industry, employees are usually stressed during service delivery. Emotional support resources and cognitive resources are noted to be of high value to an employee; (Trougakos et al., 2014). Shao and Skarlicki (2014) investigated the effect of stress on employees. The findings are broadly consistent with studies in the extant literature, notably that employee stress originates from diverse sources, inter alia: long working hours (Kensbock et al., 2015), or contact with other employees (Ineson et al., 2013), which drains the employees' psychological strength and triggers organizational negative outcomes, such as emotional exhaustion and the turnover intention (Lee and Ok, 2014). Moreover, the theory postulates' that employees are able to withstand both negative and positive adverse working conditions, and at the same time protect their resources. Transforming disappointing and unfavorable situations into conditions that are favorable and positive, to create job satisfaction and thus reach the organizational objectives, is of benefit to the organization. It is in the light of this ability to transform uncomfortable situations into promising avenues that employees with high level efficacy absorb emotional energy and remain immune to a supervisor's uncivil behavior. This builds on the fact that the theory is based on resources' depletion (Hoges and Park, 2013).

\section{Literature review and hypotheses devel- opment}

\section{Supervisor Incivility and Employee Self-Efficacy}

Adopting ideas from the conservation of resources theory, employees tend to conserve resources, and in a situation where the deposited resources are not regained, stress is inevitable. According to Schreurs et al., (2010), employees that distance themselves from a supervisor's rude behavior conserve the acquired resources; this drains their emotions and transforms job stresses into strengths (Schreurs et al., 2010). It is interesting to note that one of the causes of supervisor incivility is the high level of power associated with the supervisor's job description (Cortina et al., 2001). Following the trend of research, scholars have established that incivility causes more harm than good (Schilpzand et al., 2016; Itzkovich and Heilbrum, 2016). Self-efficacy is related to employee motivation, which aids employees in accomplishing a given task. According to the work of recent scholars (Taylor and Kluemper, 2012; Sakurai and Jex, 2012), the mechanisms that alleviate the negative effect of su- 
pervisor incivility in the workplace are on the increase, and one such measure is to increase the employees' self-efficacy. Therefore, since employee self-efficacy is a positive psychological capital, and it will possibly reduce the effect of supervisor incivility on employees, we proposed the following hypothesis.

H1: Supervisor incivility negatively influences self-efficacy.

\section{Supervisor Incivility and Job Embed- dedness and Cynicism}

In recent decade scholars (Sliter et al., 2012; Sakurai and Jex, 2012) became interested in finding ways to curtail supervisor incivility and its effect on employees. Supervisor incivility is characterized by the uncivil behavior of a supervisor toward an employee; this harmful act includes avoiding the employee, and gossiping and uttering negative comments about him/her (Reio and Sanders, 2011); this is detrimental to both the employee and the organization. Supervisor incivility is more harmful than other forms of incivility (customer incivility and co-worker incivility) because of the organizational authority vested in the supervisor to manage several concerns, including behavioral issues. Most often, when low-intensity incivility is not controlled, it affects organizational outcomes (Holm et al., 2015). Furthermore, incivility is linked with poor behavior at work. For example, workplace incivility causes a decline in job performance and an increase in employee turnover intentions (Porath and Pearson, 2012; Wilson and Holmvall, 2013; Haider et al. 2018), decreased work engagement (Chen et al., 2013) and increased levels of absenteeism (Sliter et al., 2012). In the extant literature of Bunk and Magley (2013), they pointed out that incivility leads the target to reciprocate in an uncivil way. The study by Haider et al. (2018), into the effect of bad leadership on the turnover intention in pharmaceutical companies, found out that destructive leadership is positively related to deviant behavior and turnover intention. Also, Sliter et al. (2012) and Taylor et al. (2012) noted that incivility makes employees less creative and eventually decreases citizenship behavior, which can trigger anger and distrust in the organization (Bunk and Magley, 2013). Job embeddedness is negatively related to turnover and influence's employee behavior and their working attitude (Crossley et al., 2007). Although job embeddedness is positively correlated with job satisfaction (Lee et al., 2014), Crossley et al., (2007), added that employees stick with their job as a result of positive experiences they have with their organization, community, and supervisor. Therefore, we argue that linking job embeddedness and supervisor incivility will have a negative association, since there is a strong indication that job embeddedness is the thing that unites an employee with his/her organization. On the other hand, cynicism is the defensive attitude of an employee toward an unhealthy behavior, either by the top management or by the organization (Abraham, 2000). It is a feeling that the organization cannot be trusted and lacks integrity (Bernerth et al., 2007). The COR theory suggests that an employee uses a defense mechanism in response to a supervisor's uncivil behavior. In addition, a cynical employee badmouths the organization (Wilkerson, Evans and Davis, 2008), and tries to reduce organizational commitment and organizational performance (Bernerth et al., 2007).

It is reasonable to state that supervisor incivility has an effect on employees' attitudes. A negative attitude towards the organization warrants the employee to exhibit 
unruly behavior. Hence, we propose the following underpinning hypotheses.

\section{H2: Supervisor incivility negatively influence job em- beddedness}

H3: Supervisor incivility positively influence cynicism

\section{Employee Self-Efficacy, Job Embed- dedness, and Cynicism}

Instructively, Bandura (2012) and Ho and Gupta (2014) posited that self-efficacy is the capacity to carry out a given task effectively and ensure a successful outcome despite challenges. It is a motivational construct that influences an employee's behavior, attitude, and choice of activity in a range of contexts. The regulation of effort constitutes one of the core characteristics of self-efficacy. Several studies have linked self-efficacy with a multitude of outcomes, inter alia positive organizational outcomes (Van et al., 2011), work engagement and intrinsic motivation (Brown et al., 2014), self-identity and training performance (Fan and Lai, 2014) and effective work outcomes (Judge and Bono, 2001). Additionally, self-efficacy is associated with persistent and positive organizational outcomes (Salanova et al., 2011). On the other hand, the previous literature has positively linked job embeddedness with positive organizational outcomes, like satisfaction (Ferreira et al., 2017), innovative work behavior (Haider and Akbar, 2017), creative performance (Karatepe, 2016) and work engagement (Arasli et al., 2017). Job embeddedness has on-the-job and off-the-job factors associated with an individual's links, fit, and sacrifice (Mitchel et al., 2001). Suffice to say that efficacious employees are "goal-getters" (Bandura, 2012), finding a positive alternative to every situation (Hannah et al., 2007). Conversely, cynicism negatively affects organizational outcomes by lowing organizational citizenship behavior (Jung and Kim, 2012) and employee performance (Bommer et al., 2005). A negative ripple effect is believed to ensue from a cynical employee to other employees and the organization at large. Therefore, since self-efficacy influences behavior, this study proposed that self-efficacy will have an effect on both job embeddedness and cynicism. The study proposed that self-efficacy has a link with job embeddedness and cynicism.

H4: Selfefficacy positively influences job embeddedness.

H5: Self-efficacy negatively infuences cynicism.

\section{Employee Self-Efficacy as a Mediator}

Specifically, self-efficacy is associated with job satisfaction (McNatt and Judge, 2008), turnover intentions (Avey, Luthans, and Jensen, 2009), task performance (Avey, Reichard, Luthans, and Mhatre, 2011) and organisational citizenship behaviour (OCB) (Walumbwa, Hartnell, and Oke, 2010). We drew from the conservation of resources theory and the self-efficacy theory to explain our hypothetical relationship. The regulation of one's behavior requires extra carefulness (e.g. self-efficacy) to withstand emotional absorption as a result of a negative organizational outcome (such as a supervisor's incivility). Shao and Skarlicki (2014) carried out research into the application and effect of stress on frontline employees and established a negative correlation. Employee stress emanates from diverse sources, inter alia: long working hours (Kensbock et al., 2015), contact with other employees which drains the employees' psychological strength (Ineson et al., 2013) and triggers negative outcomes (Lee and Ok, 2014). This theory proposed that employee self-efficacy pro- 
tects individual resources since the theory is based on the depletion of resources (Hoges and Park, 2013). Applying the self-efficacy theory, Bandura (1977) maintained that action is predetermined, stressing that the theory stipulates that since self-efficacy is an important aspect of human behavior, ry to our model, we propose the following hypotheses:

H6: Self-efficacy mediates the relationship between supervisor incivility and job embeddedness.

H7: Self-efficacy mediates the relationship between supervisor incivility and cynicism.

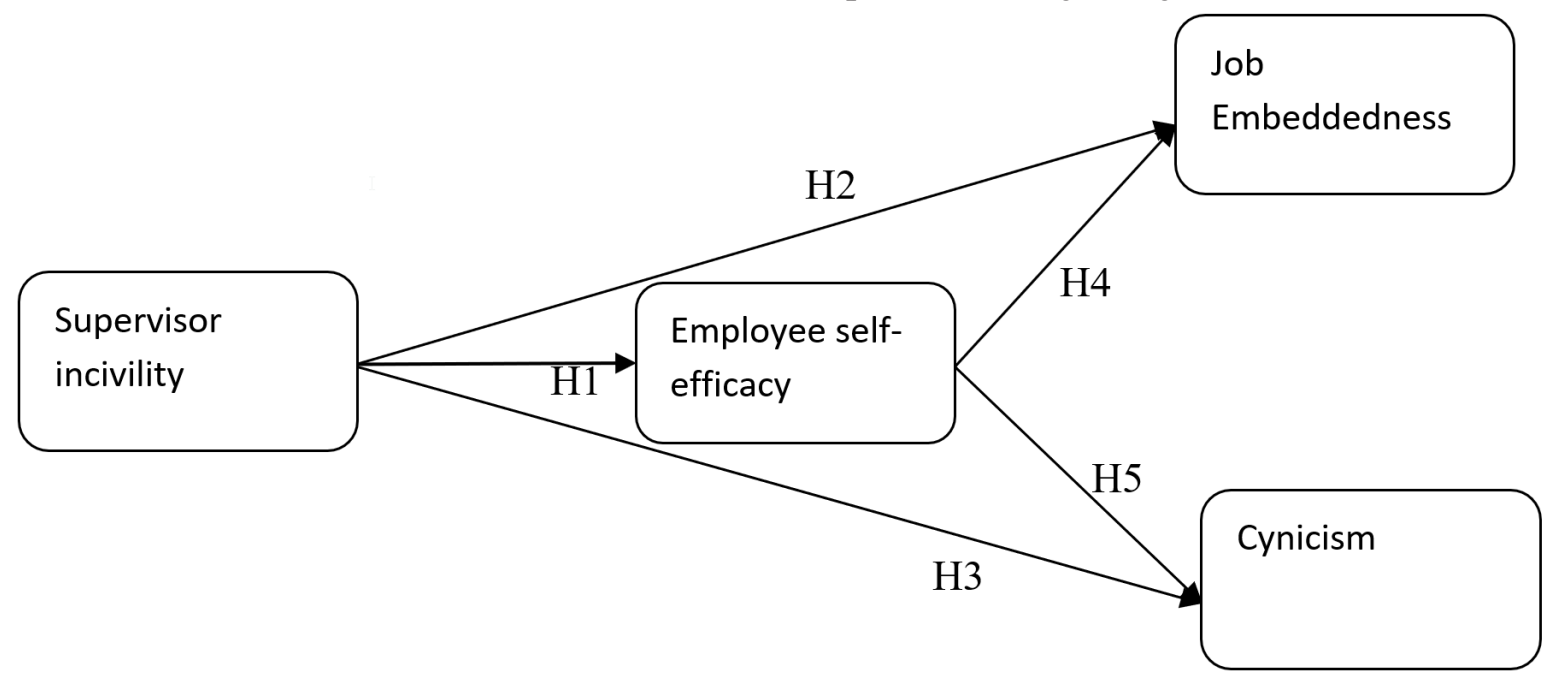

control over any reaction to organizational stress is easily obtainable. Researchers linked self-efficacy to other variables (Taylor et al., 1984; Stumpf et al., 1987, Alola et al., 2018) and found a positive relationship. In this respect, a study by Burger (1989) reviewed that events can go beyond an individual's control, leading to a negative outcome. On the other hand, Jex et al., (2001) opined that self-efficacy influences employee behavior through the way they react to events (coping). Stating that employees with low self-efficacy use more emotionally focused coping than employees with high self-efficacy. Researchers have reported that employees with high self-efficacy report less stress and less mental distortion whereas employees with low self-efficacy often display job dissatisfaction, the turnover intention and emotional depression (Judge and Bono, 2001; Semmer, 2003; Siu et al., 2007). Therefore, applying the COR theory and the self-efficacy theo-

\section{Research Methodology}

\section{Measurement}

This study adopts a quantitative approach to analyze the data. Questionnaires were designed and separated into five parts, namely; demographic variable, supervisor incivility, employee self-efficacy, job embeddedness, and cynicism. Data were collected from four- and five-star hotels in the two major Nigerian cities: Lagos and Abuja. With a non-probability sampling technique, the sample for the study is selected from a given population that represents the whole population. Investigation of the subset of the population was the most appropriate approach for the data's collection (Wang and Wang 2017; Bornstein et al., 2013). The sample size was determined based on the researcher's judgment, since no data was available to determine 
the survey population's size (Darvishmotevali et al., 2017). In addition, the researcher used only hotel employees that have direct contact with the customers.

In order to test the validity of the questionnaire, a pilot study was conducted with 30 respondents, to establish face validity. A total of 450 questionnaires were distributed to customer contact employees. Prior to the distribution of the questionnaires, a letter was sent to the management of the relevant hotels to ask for permission, and to assure them of the confidentiality of their identities. The questionnaires were sealed after collection to make the responses anonymous and to decrease the potential threat of common method bias (Podsakoff et al., 2003). Out of the 450 questionnaires that were distributed, only 245 questionnaires were completed and returned, excluding the ones that were half-completed or incorrectly completed, yielding a response rate of $54.4 \%$.

\section{Measures}

The study Measures were adopted from previous studies, the employees were asked to explain what happened in their encounter with their supervisor and how this encounter affected their personality and their relationship with the organization.

Supervisor incivility: adopted from the work of Hur et al. (2016) with five items (for example, (i) the supervisor was condescending to me, (ii) the supervisor showed little interest in my opinions, (iii) the supervisor made demeaning remarks about me).

Employee self-efficacy: adopted from the work of Peak et al. (2015) with five items (for example, (i) I feel confident analyzing a long-term problem to find a solution, (ii) I feel con- fident in presenting my work area at meetings with management, (iii) I feel confident contributing to discussions about my hotel's strategy).

Cynicism (Depersonalization): cynicism was adopted from the study of Maslach et al. (1996) with five items (for example, (i) I feel I treat some recipients as if they were inhuman, (ii) I have become more callous toward people since I took this job, (iii) I worry that this job is hardening me emotionally).

Job embeddedness: job embeddedness was adopted from the study of Karatepe (2013) with seven items (for example, (i) I feel attached to this hotel, it would be difficult for me to leave this hotel, (ii) I am too caught up in this hotel to leave, (iii) I feel tied to this hotel).

All four measures were rated on a fivepoint Likert scale ranging from strongly disagree $=$ one to strongly agree $=$ five .

\section{Data analysis}

\section{Descriptive Statistics of the Respon- dents}

Out of the 245 questionnaires that were used for the study, 165 were from males and 80 were from females. Almost all the respondents were less than 42 years old, only 18 were 42 years old and above. More than half of the respondents were single, accounting for $51.8 \%$, while the rest were either married, divorced or widowed. Nearly two-thirds (or $59.6 \%$ of the respondents have a master's degree, two have a primary school certificate and the rest have either a secondary school or an undergraduate certificate. Of the total respondents, 97 have worked for between 4-6 years, and 63 have worked for seven years 
Gadjah Mada International Journal of Business - Sept.-Dec., Vol. 21, No. 3, 2019

and above, while the rest have worked for less than four years.

on the basis of a number of fit statistics, CMIN/DF $=2.218$; GFI (Goodness of Fit Index) $=0.871$; AGFI (Adjusted Goodness

Table 1: Descriptive Statistics of Respondents

\begin{tabular}{|c|c|c|}
\hline Characteristics & Frequency & Percentage \\
\hline \multicolumn{3}{|l|}{ Gender } \\
\hline Male & 165 & 67.3 \\
\hline Female & 80 & 32.7 \\
\hline Total & 245 & 100 \\
\hline \multicolumn{3}{|l|}{ Age } \\
\hline $18-25$ & 27 & 11 \\
\hline $26-33$ & 97 & 39.6 \\
\hline $34-41$ & 103 & 42 \\
\hline $42-49$ & 18 & 7.3 \\
\hline Total & 245 & 100 \\
\hline \multicolumn{3}{|l|}{ Marital status } \\
\hline Single & 127 & 51.8 \\
\hline Married & 107 & 43.7 \\
\hline Divorced & 8 & 3.3 \\
\hline Widow/widower & 3 & 1.2 \\
\hline Total & 245 & 100 \\
\hline \multicolumn{3}{|l|}{ Education } \\
\hline Primary & 2 & 8 \\
\hline Secondary & 25 & 10.2 \\
\hline Graduate & 72 & 29.4 \\
\hline Masters & 146 & 59.6 \\
\hline Total & 245 & 100 \\
\hline \multicolumn{3}{|c|}{ Organizational tenure } \\
\hline Less than a year & 26 & 10.6 \\
\hline $1-3$ years & 59 & 24.1 \\
\hline $4-6$ years & 97 & 39.6 \\
\hline 7 and above & 63 & 25.7 \\
\hline Total & 245 & 100 \\
\hline
\end{tabular}

\section{Model Fit Indexes}

To further test the model's fit, we employed Analysis of Moment Structures (IBM AMOS 20 Statistics). The results indicated a good fit of the four-factor model to the data, of Fit Index) $=0.832$; IFI (Incremental Fit Index $)=0.920$; CFI (Comparative Fit Index) $=0.920$; RMSEA (Root Mean Square Error of Approximation) $=0.071$; RMSR (Root Mean Square Residual) $=0.062$ (Byrne, 2001). 
In addition, Cronbach's alpha was tested to determine the internal consistency of the variables. Specifically, the Cronbach's alpha scores ranged from 0.877 to 0.798 respectively. The results indicated that all the coefficients' alpha scores were greater than 0.70 , hence the measures are considered reliable (Nunnally, 1978). values for the entire construct were higher than the cutoff point of 0.50 (Fornell and Larcker, 1981; Cavana et al., 2001). The result established the evidence of convergent validity. For the composite reliabilities, the scores ranged from 0.799 to 0.881 , exceeding the cutoff point of 0.70 (Fornell and Larcker, 1981) indicating adequate internal consisten-

Table 2: Confirmatory Factor Analysis (CFA)

\begin{tabular}{|c|c|c|c|}
\hline Supervisor Incivility & & 0.799 & 0.501 \\
\hline The supervisor's action was condescending to me. & 0.72 & & \\
\hline The supervisor showed little interest in my opinion. & 0.74 & & \\
\hline The supervisor made demeaning remarks about me. & 0.84 & & \\
\hline $\begin{array}{l}\text { The supervisor addressed me in unprofessional terms, either publicly or pri- } \\
\text { vately. }\end{array}$ & 0.73 & & \\
\hline The supervisor ignored or excluded me from professio discussions. & 0.75 & & \\
\hline Self-Efficacy & & 0.871 & 0.575 \\
\hline I feel confident analyzing a long-term problem to find a solution. & 0.73 & & \\
\hline I feel confident in presenting my work area in meetings with management. & 0.87 & & \\
\hline I feel confident contributing to discussions about my hotel's strategy. & 0.82 & & \\
\hline I feel confident helping to set targets/goals in my work area. & 0.84 & & \\
\hline $\begin{array}{l}\text { I feel confident contacting people outside my hotel (e.g., customers) to discuss } \\
\text { problems. }\end{array}$ & 0.5 & & \\
\hline
\end{tabular}

\begin{tabular}{lll}
\hline Job embeddedness & 0.881 & 0.562 \\
\hline I feel attached to this hotel. & 0.8 & \\
\hline It would be difficult for me to leave this hotel. & 0.83 & \\
\hline I am too caught up in this hotel to leave. & 0.94 & \\
\hline I feel tied to this hotel. & 0.75 \\
\hline I simply could not leave the hotel that I work for. & 0.58 & \\
\hline I am tightly connected to this organization. & 0.51 & 0.585 \\
\hline Cynicism & & \\
\hline I have become more callous toward people since I took this job. & 0.7 & 0.78 \\
\hline I worry that this job is hardening me emotionally. & 0.72 & \\
\hline I do not really care what happens to some recipients. & 0.67 & \\
\hline I feel recipients blame me for some of their problems. & & \\
\hline
\end{tabular}

Note. Model fit statistics, CMIN/DF =2.218; GFI (Goodness of Fit Index) $=0.871$; AGFI (Adjusted Goodness of Fit Index $=0.832$; IFI (Incremental Fit Index $)=0.920$; CFI (Comparative Fit Index $)=0.920$; RMSEA (Root Mean Square Error of Approximation) $=0.071$; RSR (Root Mean Square Residual) $=0.062$.

The result of the CFA are shown in Table 2, the Average Variance Extracted (AVE) cy. The Average Variance Extracted (AVE) is higher than the square correction (R2) 
Gadjah Mada International Journal of Business - Sept.-Dec., Vol. 21, No. 3, 2019

Table 3. Means, Standard Deviation and Correlations of the Study

\begin{tabular}{lllllll}
\hline Variables & M & SD & 1 & 2 & 3 & 4 \\
\hline 1. Supervisor incivility & 2.7 & 0.85 & - & & \\
\hline 2. Self-efficacy & 3.7 & 0.75 & $-0.293^{* *}$ & - & - \\
\hline 3. Cynicism & 2.4 & 0.75 & $0.322^{* *}$ & $-0.334^{* *}$ & - \\
\hline 4. Job embeddedness & 2.6 & 0.77 & $-0.235^{* *}$ & $0.365^{* *}$ & $0.331^{* *}$ & - \\
\hline
\end{tabular}

Note Composite scores for each variable were computed by averaging the respective item's score.* denotes the correlation is significant $\mathrm{p}<0.01$ and $* *(t=1.67)$ correlation is significant at $\mathrm{p}<0.05(\mathrm{t}=1.96) . \mathrm{M}=\mathrm{Mean}, \mathrm{SD}=$ Standard

between the pair of constructs, establishing discriminate validity. In Table 3 , the means, standard deviation, and correlations of the variables are presented. The result shows that supervisor incivility is negatively correlated to self-efficacy, $\left(\mathrm{r}=-0.293^{* *}, \mathrm{p}<0.01\right)$ and job embeddedness $\left(\mathrm{r}=-0.235^{* *}, \mathrm{p}<0.01\right)$ but positively correlated to cynicism ( $\mathrm{r}=$ $\left.0.322^{*}, \mathrm{p}<0.01\right)$. On the other hand, self-efficacy is negatively correlated to cynicism ( $\mathrm{r}=$ $\left.-0.334^{* *}, \mathrm{p}<0.01\right)$, but positively correlated to job embeddedness $\left(\mathrm{r}=0.365^{* *}, \mathrm{p}<0.01\right)$, whereas cynicism is negatively correlated to job embeddedness $\left(\mathrm{r}=-0.331^{* *}, \mathrm{p}<0.01\right)$. employee self-efficacy and job embeddedness, but a positive effect on cynicism) results were presented. The study found out that supervisor incivility has a negative effect on self-efficacy $\left(\beta=-0.289^{* *}, \mathrm{p}<0.01\right)$ and a positive effect on cynicism $\left(\beta=0.322^{* *}, \mathrm{p}\right.$ $<0.01)$. Our study failed to establish a negative relationship between supervisor incivility and job embeddedness $(\beta=0.080)$; therefore, both Hypothesis 1: (i.e, supervisor incivility negatively influences self-efficacy) and Hypothesis 3: (i.e, supervisor incivility is positively related to cynicism) were accepted, while Hypothesis 2: (i.e, supervisor inci-

Table 4: Result of Path Analysis

\begin{tabular}{lcll}
\hline Parameters & Standardized Estimates & t-values & $\mathrm{R}^{2}$ \\
\hline Direct effect & & & \\
$\mathrm{SUP} \longrightarrow \mathrm{EFF}$ & -0.289 & $-4.665^{* *}$ & 0.099 \\
$\mathrm{SUP} \longrightarrow \mathrm{JOB}$ & 0.080 & 1.228 & 0.023 \\
$\mathrm{SUP} \longrightarrow \mathrm{CYN}$ & 0.322 & $5.150^{* *}$ & 0.115 \\
$\mathrm{EFF} \longrightarrow \mathrm{JOB}$ & 0.045 & 0.691 & 0.021 \\
$\mathrm{EFF} \longrightarrow \mathrm{CYN}$ & -0.342 & $-5.523^{* *}$ & 0.023
\end{tabular}

$\mathrm{SUP}=$ supervisor incivility; $\mathrm{EFF}=$ self-efficacy; JOB = job embeddedness; $\mathrm{CYN}=$ cynicism

The results above show that the first three conditions of Baron and Kenny's (1986) on the condition on mediation was established.

In Table 4, the hypotheses (that supervisor incivility will have a negative effect on vility is negatively related to job embeddedness) was rejected. From the proposition that self-efficacy will have a positive effect on job embeddedness and a negative effect on cynicism, our result shows that self-efficacy has no effect on job embeddedness $(\beta=0.045)$ 
Alola et al

but it is negatively related to cynicism $(\beta=$ $-0.342 * *, p<0.01)$. Therefore, Hypothesis 4 (i.e. that self-efficacy is positively related to job embeddedness) was rejected and Hy- and job embeddedness, and as such Hypothesis 5 was rejected. On the other hand, there was mediation for Hypothesis 6, as shown in Table 5 above. When the mediating variable

Table 5. Mediating effect of self-efficacy on job embeddedness and cynicism

\begin{tabular}{|c|c|c|c|c|c|c|}
\hline \multirow[t]{2}{*}{ Variables } & \multicolumn{3}{|c|}{ Job embeddedness } & \multicolumn{3}{|c|}{ Cynicism } \\
\hline & $\beta$ & $\beta$ & $\beta$ & $\beta$ & $\beta$ & $\beta$ \\
\hline \multicolumn{7}{|l|}{ Control Variables } \\
\hline Gender & -0.127 & -0.119 & -0.127 & -0.142 & $-0.107 *$ & -0.084 \\
\hline Age & 0.120 & 0.114 & 0.111 & -0.034 & -0.063 & -0.054 \\
\hline Marital Status & 0.111 & 0.116 & 0.122 & 0.001 & 0.025 & 0.007 \\
\hline Education Qualification & 0.000 & 0.000 & 0.006 & -0.137 & $-0.135^{* *}$ & $0.154^{* *}$ \\
\hline Organizational Tenure & $-0.096 * *$ & -0.084 & -0.094 & $-0.182 * *$ & $*-0.129 *$ & -0.099 \\
\hline Independent & & & & & & \\
\hline $\begin{array}{l}\text { Supervisor incivility } \\
\text { Mediator }\end{array}$ & - & 0.067 & 0.090 & - & $0.294^{* *}$ & $0.225^{* *}$ \\
\hline $\begin{array}{l}\text { Self-efficacy } \\
0.254^{* *}\end{array}$ & - & - & 0.081 & - & - & - \\
\hline $\mathrm{R}^{2}$ at each step & 0.051 & 0.056 & 0.062 & 0.074 & 0.158 & 0.215 \\
\hline$\Delta \mathrm{R}^{2}$ & - & 0.004 & 0.006 & - & 0.083 & 0.057 \\
\hline $\mathrm{F}$ & $2.59 * *$ & $2.35^{* *}$ & $2.23 * *$ & $3.84 * *$ & $7.42 * *$ & $9.27 * *$ \\
\hline
\end{tabular}

SUP $\rightarrow$ JOB

0.9409 SUP

$\mathrm{CYN} 3.174^{* *}$

$\mathrm{SUP}=$ supervisor incivility; $\mathrm{EFF}=$ self-efficacy; $\mathrm{JOB}=$ job embeddedness; $\mathrm{CYN}=$ cynicism; One tailed test $(\mathrm{t}>1.65)$, and two test $(\mathrm{t}>1.96)$.

pothesis 5 (i.e, that employee self-efficacy is negatively related to cynicism) was accepted.

We tested for the mediating effect of self-efficacy on the study model. There was a reduction in the size of the model when self-efficacy was added, and the result was not significant $(\beta=0.081)$, but there was significant evidence of an increment in R2 (0.004, versus 0.006). This initial result was later confirmed using the Sobel test calculation $(z=0.9409)$. The findings failed to support the argument that self-efficacy mediates the relationship between supervisor incivility (self-efficacy) was inputted into the model, the size of the model significantly reduced $(\beta=0.225 \mathrm{p}<0.05)$ and there was a significant reduction in R2 (0.083 versus 0.057$)$. Then the Sobel test $(z=3.174 \mathrm{p}<0.01)$ confirmed and supported our initial assumption that self-efficacy mediates the relationship between supervisor incivility and cynicism, hence Hypothesis 6 was accepted. For the demographic variables, age, educational qualifications and organizational tenure all have significant negative relationships with supervisor incivility. Educational qualifica- 
tions have a negative significant relationship with self-efficacy. This further explains why frontline employees who are older and have a good education with longer tenure at an organization exhibit stronger self-efficacy and withstand supervisor incivility better. Also, employees that are highly educated are likely to be less self-efficacious.

\section{Discussion}

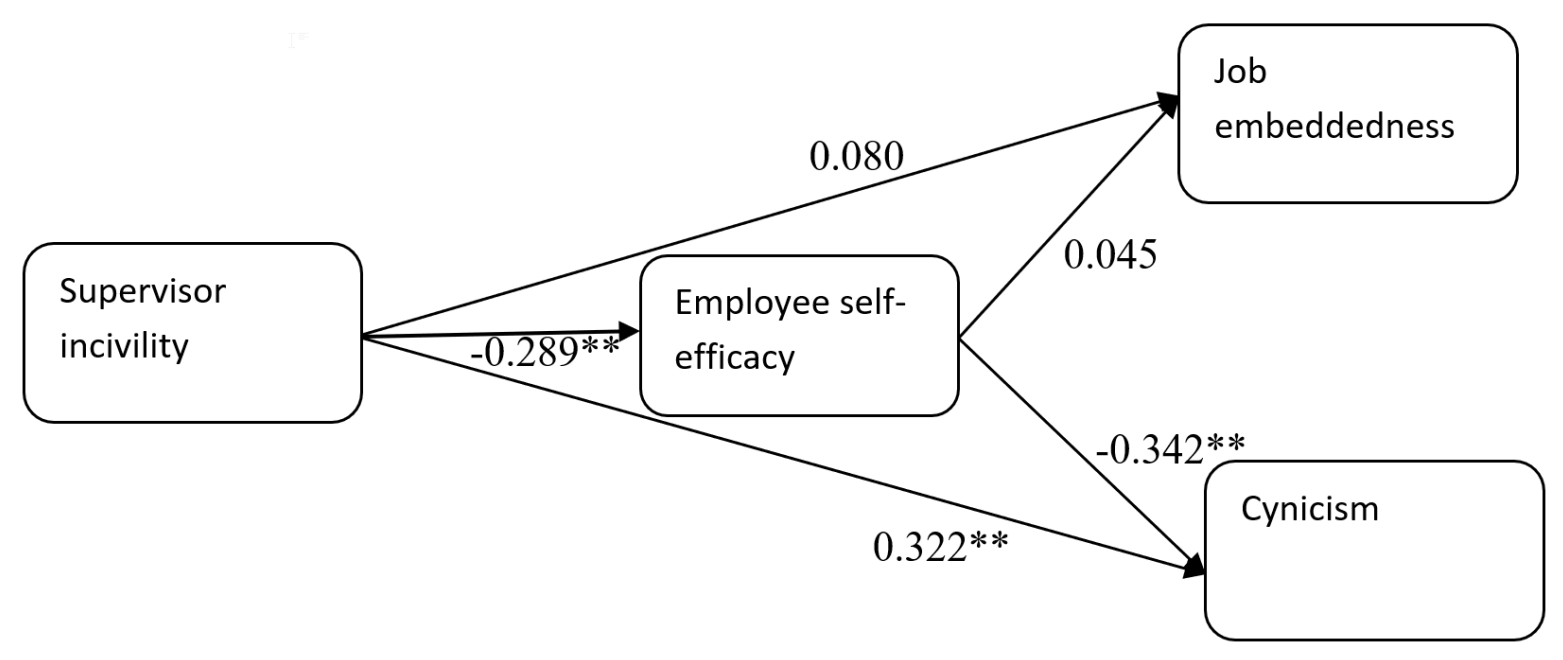

Figure 2: Result of the research model.

With the increasing complexity of organizational structures and the negative externalities associated with the underlying complexity, support from both supervisors and organizations is crucial for employees, especially customer-contact employees. According to Hom et al. (2009), employees who feel fairly treated have strong ties with their organization. Since supervisors embody the organization and give directives (Eisenberger et al., 2010), fostering good relationships with employees is crucial for establishing and promoting good behavior (Collins, 2017; Collins et al., 2014). As evident in the present study, supervisor incivility negatively affects employee self-efficacy, as affirmed in pre- vious studies into self-efficacy and bullying (Mikkelsen and Einarsen, 2002; Roberts et al., 2011). According to Taylor and Kluemper (2012) and Sakurai and Jex (2012), self-efficacy is one major mechanism that mitigates supervisor incivility. This suggests that a self-efficacious employee's copying capability increases with the perception of supervisor incivility. Therefore, human resource managers should develop mechanisms for the enhancement of self-efficacy. 
ployees may engage in deviant behavior, "cynicism". Also, our findings are consistent with the work of Laschinger et al. (2008), which established that employees who experience supervisors' uncivil acts are most likely to be cynics. This study is also in line with the works of Erdogan (2002) and Colquitt et al. (2001) which established that job demands result in negative job outcomes. Less embedded employees are not likely to feel the influence of unfair treatment when subject to supervisor incivility. This reduces the ability of frontline employees to identify with the organization and they tend toward cynical behavior (Elsbach and Bhattacharya, 2001). Organizations do not tolerate cynical behavior because of its harmful effect on both the organization and the employees. Also, Chiaburn et al. (2013) pointed out that employees that do not display cynical behavior have greater job satisfaction and perform better at work. Therefore, incivility should neither be tolerated nor accepted in an organization. It is interesting to note that the study could not establish a direct relationship between self-efficacy and job embeddedness. Unfortunately, employees who are self-efficacious are not likely to be embedded, and there is no significant relationship between supervisor incivility and job embeddedness. Less embedded employees are not likely to feel the influence of any unfair treatment by their supervisors. This makes the frontline employees that are affected less interested in the organization and they tend toward cynicism (Elsbach and Bhattacharya, 2001).

\section{Implications, Theory and Practice}

\section{Theoretical Implications}

The conservation of resources theory (Hobfoll, 1989) and the self-efficacy theory (Bandura, 1977) provide an insight into the present study. This theory applies the significance of the employees' accumulation, protection, and allocation of valued resources in response to their work demand (Hobfoll and Freedy, 1993). The study employs this theoretical finding to contribute significantly in different ways to the current literature on supervisor incivility and self-efficacy. Our study investigates the effects of supervisor incivility on job embeddedness and cynicism, and the mediating effect of self-efficacy. Cynicism represents an effective reaction to the gradual depletion of the psychological powers and wellbeing that frontline employees encounter from their supervisors' incivility (Maslach et al., 2001). The tested hypotheses in this study contribute to the theory-building, since it is vital for established theories to withstand empirical scrutiny across time and scope, in order to remain relevant to organizations, corporations, and society in general.

\section{Practical Implications}

The study provides vital information for human resource managers in the hotel industry as well as managers in other related sectors. The rapid rise in supervisor incivility has constantly led to deviant organizational behavior (cynicism) in recent years, and this has raised concerns in researchers. The quest to control supervisors' and employees' negative behavior is on the increase. This study contributes to practical advancements in the hospitality management industry by empirically testing the relationship between supervisor incivility, cynicism, job embeddedness and the mediating role of self-efficacy. In practical terms, human resources managers need to constantly train and educate supervisors on the benefits of polite interactions with other employees. According to Mackey et al. (2017), employees who are trained behave better than 
their untrained counterparts. Supervisors are expected to develop a cordial relationship with their subordinates, in order to influence their constructive and positive behavior. Educating supervisors is done through seminars and workshops. Researchers have agreed that employee education is very vital for any organization, and the benefits out-weigh the costs (Bowers and Martin, 2007; Eisingerich and Bell, 2008). Also, supervisors' behavior can also be checked in the following way: Firstly, supervisors will receive performance appraisals at the end of each month, these include the employees' confidential ratings of them. This monitoring exercise will enhance the supervisors' positive behavior. In turn, supervisors with the worst performance scores can be called to order, while promoting and rewarding those with the highest scores. This mechanism will not only be of benefit to the frontline employees, but also to the organization, because supervisors' incivility negatively affects the employees' emotions (Halbesleben and Bowler, 2007). Also, unruly behavior by a supervisor is checked, to avoid it escalating into cynicism (Abubakar et al., 2017). Secondly, since the hotel industry constantly faces very stiff competition, frontline employees are of the utmost importance to every service organization. Hence, fair policies that will be of benefit to the frontline employees should be enacted to prevent the employees' frequent turnover intentions. Most employees who are involved in cynical behavior might end-up quitting the organization and the cost of retaining an employee is less than that of training a new employee. Thirdly, employee embeddedness is important to an organization, frequent supervisor-employee positive interactions buttress the fact that an organization has the best interests of its employees at heart (Collins, 2017). Therefore, both the supervisors and the managers should give employees a sense of belonging, by making the employees feel that they are not just working for the organization, but they are part of the organization. Employees can be empowered by making them part of the decision-making process, especially in vital decisions that affect their roles in the organization. This approach has been established to decrease employees' cynical behavior (Abubakar et al., 2017). Finally, self-efficacy, which is the self-consciousness of one's ability and beliefs, is increased through employee education, appraisals, and promotions, which strengthen the employees' emotional states to withstand their supervisors' incivility and increases positive organizational behavior.

\section{Conclusion, Limitations and Future Research Recommen- dations}

This study examined the effect of supervisor incivility on job embeddedness and cynicism via the mediating role of self-efficacy. A convenience sampling technique was used to collect data from frontline employees of five-star and four-star hotels in the cities of Lagos and Abuja in Nigeria. The study used a cross-sectional method for the collection of data and a quantitative approach with SPSS and AMOSS 20 to analyze the data. The assessment of the various underpinning relationships has broadly shown that supervisor incivility is detrimental to both the employees and their organizations. Also, the findings show that supervisor incivility leads to cynical behavior by the employees. Seven hypotheses have been tested, and based on the findings human resources managers were advised of the benefits of employee self-efficacy and the protective role of self-efficacy against supervisor incivility and cynicism. These re- 
sults are encouraging because self-efficacy can be supported or promoted by proactive human resources managers. Human resources manages can endeavor to create working conditions that reduce supervisor incivility and subsequently curtail cynicism, which is detrimental to both the employees and the organizations at large.

Although this study contributes to the extant literature by linking supervisor incivility, self-efficacy and cynicism in the hotel industry, limitations to this work cannot be ruled out. The present study made use of cross-sectional data; other studies can use longitudinal data. As more data become available, the temporal and geographical scopes of the study can be broadened in the light of a longitudinal approach to the data's analysis, in order to assess if the established findings withstand further empirical scrutiny. The study was conducted in the Nigerian hotel industry; further studies can be done in other industries, inter alia: airlines, health, and restaurant industries. Therefore, in interpreting the results, caution should be employed to avoid generalizations because the data were collected only from the Nigerian hotel industry.

\section{Reference}

Abraham, R. 2000. Organizational cynicism: Bases and consequences. Genetic, social, and general psychology monographs, 126(3), 269.

Abubakar, A. M., Abubakar, A. M., Arasli, H., and Arasli, H. 2016. Dear top management, please don't make me a cynic: intention to sabotage. Journal of Management Development, 35(10), 1266-1286.

Abubakar, A. M., Namin, B. H., Harazneh, I., Arasli, H., and Tunç, T. 2017. Does gender moderates the relationship between favoritism/nepotism, supervisor incivility, cynicism and workplace withdrawal: A neural network and SEM approach. Tourism Management Perspectives, 23, 129-139.

Akadiri, S. S., Akadiri, A. C., and Alola, U. V. 2017. Is there growth impact of tourism? Evidence from selected small island states. Current Issues in Tourism, 1-19.

Alola, A. A., and Alola, U. V. 2018. Agricultural land usage and tourism impact on renewable energy consumption among Coastline Mediterranean Countries. Energy and Environment, $0958305 X 18779577$.

Alola, U. V., and Alola, A. A. 2018. Can Resilience Help? Coping with Job Stressor. Academic Journal of Economic Studies, 4(1), 141-152.

Alola, U. V., Olugbade, O. A., Avci, T., \& Öztüren, A. (2019). Customer incivility and employees’ outcomes in the hotel: Testing the mediating role of emotional exhaustion. Tourism Management Perspectives, 29, 9-17.

Alola, U., Avci, T., \& Ozturen, A. (2018). Organization Sustainability through Human Resource Capital: The Impacts of Supervisor Incivility and Self-Efficacy. Sustainability, 10(8), 2610. 
Gadjah Mada International Journal of Business - Sept.-Dec., Vol. 21, No. 3, 2019

Anderson, L. 1996. Employee cynicism: An examination using a contract violation framework. Human Relations, 49, 1395-1418.

Andersson, L. M., and Pearson, C. M. 1999. Tit for tat? The spiraling effect of incivility in the workplace. Academy of management review, 24(3), 452-471.

Arasli, H., Bahman Teimouri, R., Kiliç, H., and Aghaei, I. 2017. Effects of service orientation on job embeddedness in hotel industry. The Service Industries Journal, 37(9-10), 607-627.

Aslan, S.., and Eren, S.. 2014. The effect of cynicism and the organizational cynicism on alienation. In The Clute Institute International Academic Conference (pp. 617-625)

Bandura, A. 1998. Health promotion from the perspective of social cognitive theory. Psychology and health, 13(4), 623-649.

Bandura, A. 2012. On the functional properties of perceived self-efficacy revisited.

Bernerth, J. B., Armenakis, A. A., Feild, H. S., Giles, W. F., and Walker, H. J. 2007. Leader-member social exchange (LMSX): Development and validation of a scale. Journal of Organizational Behavior: The International Journal of Industrial, Occupational and Organizational Psychology and Behavior, 28(8), 979-1003.

Bommer, W. H., Rich, G. A., and Rubin, R. S. 2005. Changing attitudes about change: Longitudinal effects of transformational leader behavior on employee cynicism about organizational change. Journal of Organizational Behavior, 26(7), 733-753.

Bowers, M. R., and Martin, C. L. 2007. Trading places redux: employees as customers, customers as employees. Journal of Services Marketing, 21(2), 88-98.

Brown, G., Crossley, C., and Robinson, S. L. 2014. Psychological ownership, territorial behavior, and being perceived as a team contributor: The critical role of trust in the work environment. Personnel Psychology, 67(2), 463-485.

Bunk, J. A., and Magley, V. J. 2013. The role of appraisals and emotions in understanding experiences of workplace incivility. Journal of Occupational Health Psychology, 18(1), 87.

Byrne, B. M. 2001. Structural equation modeling: Perspectives on the present and the future. International Journal of Testing, 1(3-4), 327-334.

Cavana, R. Y., Delahaye, B. L., and Sekaran, U. 2001. Applied business research: Qualitative and quantitative methods. John Wiley and Sons Australia.

Chen, Y., Ferris, D. L., Kwan, H. K., Yan, M., Zhou, M., and Hong, Y. 2013. Self-love's lost labor: A self-enhancement model of workplace incivility. Academy of Management Journal, 56(4), 1199-1219.

Chiaburu, D. S., Peng, A. C., Oh, I.-S., Banks, G. C., and Lomeli, L. C. 2013. Antecedents and consequences of employee organizational cynicism: A meta-analysis. Journal of Vocational Behavior, 83, 181-197. 
Cho, M., Cho, M., Bonn, M. A., Bonn, M. A., Han, S. J., Han, S. J., and Lee, K. H. 2016. Workplace incivility and its effect upon restaurant frontline service employee emotions and service performance. International Journal of Contemporary Hospitality Management, 28(12), 28882912.

Collins, B. J. 2017. Fair? I Don't Care: Examining the Moderating Effect of Workplace Cynicism on the Relationship Between Interactional Fairness and Perceptions of Organizational Support From a Social Exchange Perspective. Journal of Leadership and Organizational Studies, 24(3), 401-413.

Collins, B. J., Burrus, C. J., and Meyer, R. D. 2014. Gender differences in the impact of leadership styles on subordinate embeddedness and job satisfaction. The leadership quarterly, 25(4), 660-671.

Colquitt, J. A., Conlon, D. E., Wesson, M. J., Porter, C. O., and Ng, K. Y. 2001. Justice at the millennium: a meta-analytic review of 25 years of organizational justice research.

Cortina, L. M., Magley, V. J., Williams, J. H., and Langhout, R. D. 2001. Incivility in the workplace: incidence and impact. Journal of occupational health psychology, 6(1), 64.

Crossley, C. D., Bennett, R. J., Jex, S. M., and Burnfield, J. L. 2007. Development of a global measure of job embeddedness and integration into a traditional model of voluntary turnover. Journal of Applied Psychology, 92(4), 1031.

Eisenberger, R., Karagonlar, G., Stinglhamber, F., Neves, P., Becker, T. E., Gonzalez-Morales, M. G., and Steiger-Mueller, M. 2010. Leader-member exchange and affective organizational commitment: The contribution of supervisor's organizational embodiment. Journal of Applied Psychology, 95, 1085-1103.

Eisingerich, A. B., and Bell, S. J. 2008. Perceived service quality and customer trust: does enhancing customers' service knowledge matter?. Journal of service research, 10(3), 256-268.

Elsbach, K. D., and Bhattacharya, C. B. 2001. Defining who you are by what you're not: Organizational disidentification and the National Rifle Association. Organization Science, 12(4), 393-413.

Erdogan, B. 2002. Antecedents and consequences of justice perceptions in performance appraisals. Human resource management review, 12(4), 555-578.

Fallatah, F., Laschinger, H. K., and Read, E. A. 2017. The effects of authentic leadership, organizational identification, and occupational coping self-efficacy on new graduate nurses' job turnover intentions in Canada. Nursing Outlook, 65(2), 172-183.

Fan, J., and Lai, L. 2014. Pre-training perceived social self-efficacy accentuates the effects of a cross-cultural coping orientation program: Evidence from a longitudinal field experiment. Journal of Organizational Behavior, 35(6), 831-850.

Ferreira, A. I., Ferreira, A. I., Martinez, L. F., Martinez, L. F., Lamelas, J. P., Lamelas, J. P., and Rodrigues, R. I. 2017. Mediation of job embeddedness and satisfaction in the relationship 
Gadjah Mada International Journal of Business - Sept.-Dec., Vol. 21, No. 3, 2019

between task characteristics and turnover: A multilevel study in Portuguese hotels. International Journal of Contemporary Hospitality Management, 29(1), 248-267.

Fornell, C., and Larcker, D. F. 1981. Evaluating structural equation models with unobservable variables and measurement error. Journal of marketing research, 39-50.

Fox, S., and Spector, P. E. 1999. A model of work frustration-aggression. Journal of organizational behavior, 915-931.

Griffin, B. 2010. Multilevel relationships between organizational-level incivility, justice and intention to stay. Work and Stress, 24(4), 309-323.

Haider, M. H., and Akbar, A. 2017. Internal Marketing and Employee's Innovative Work Behavior: The Mediating Role of Job Embeddedness and Social capital. NICE Research Journal of Social Science. ISSN: 2219-4282, 10(1), 29-48.

Halbesleben, J. R. 2006. Sources of social support and burnout: a meta-analytic test of the conservation of resources model. Journal of applied Psychology, 91(5), 1134.

Halbesleben, J. R., and Bowler, W. M. 2007. Emotional exhaustion and job performance: the mediating role of motivation. Journal of applied psychology, 92(1), 93

Halbesleben, J. R., Neveu, J. P., Paustian-Underdahl, S. C., and Westman, M. 2014. Getting to the "COR" understanding the role of resources in conservation of resources theory. Journal of Management, 40(5), 1334-1364.

Hannah, S. T., Sweeney, P. J., and Lester, P. B. 2007. Toward a courageous mindset: The subjective act and experience of courage. The Journal of Positive Psychology, 2(2), 129-135.

Harvey, P., Harris, R. B., Harris, K. J., and Wheeler, A. R. 2007. Attenuating the effects of social stress: The impact of political skill. Journal of Occupational Health Psychology, 12(2), 105.

Ho, V. T., and Gupta, N. 2014. Retaliating against Customer Interpersonal Injustice in a Singaporean Context: Moderating Roles of Self-efficacy and Social Support. Applied Psychology, 63(3), 383-410.

Hobfoll, S. E. 1989. Conservation of resources: A new attempt at conceptualizing stress. American psychologist, 44(3), 513.

Hobfoll, S. E., and Freedy, J. 1993. Conservation of resources: A general stress theory applied to burnout.

Hodges, A. J., and Park, B. 2013. Oppositional identities: dissimilarities in how women and men experience parent versus professional roles. Journal of personality and social psychology, 105(2), 193.

Holm-Hadulla, R. M., and Koutsoukou-Argyraki, A. 2015. Mental health of students in a globalized world: Prevalence of complaints and disorders, methods and effectivity of counseling, structure of mental health services for students. Mental Health and Prevention, 3(1-2), 1-4. 
Hom, P. W., Tsui, A. S., Wu, J. B., Lee, T. W., Zhang, A. Y., Fu, P. P., and Li, L. 2009. Explaining employment relationships with social exchange and job embeddedness. Journal of Applied Psychology, 94, 277-297.

Hur, W. M., Hur, W. M., Moon, T., Moon, T., Jun, J. K., and Jun, J. K. 2016. The effect of workplace incivility on service employee creativity: the mediating role of emotional exhaustion and intrinsic motivation. Journal of Services Marketing, 30(3), 302-315.

Hur, W. M., Kim, B. S., and Park, S. J. 2015. The relationship between co-worker incivility, emotional exhaustion, and organizational outcomes: The mediating role of emotional exhaustion. Human Factors and Ergonomics in Manufacturing and Service Industries, 25(6), 701-712.

Hussain, T., \& Deery, S. (2018). Why do self-initiated expatriates quit their jobs: The role of job embeddedness and shocks in explaining turnover intentions. International Business Review, 27(1), 281-288.

Ineson, E. M., Benke, E., and László, J. 2013. Employee loyalty in Hungarian hotels. International Journal of Hospitality Management, 32, 31-39.

Itzkovich, Y., and Heilbrunn, S. 2016. The role of co-workers' solidarity as an antecedent of incivility and deviant behavior in organizations. Deviant Behavior, 37(8), 861-876.

Jex, S. M., Bliese, P. D., Buzzell, S., and Primeau, J. 2001. The impact of self-efficacy on stressorstrain relations: Coping style as an explanatory mechanism. Journal of applied psychology, 86(3), 401.

Judge, T. A., and Bono, J. E. 2001. Relationship of core self-evaluations traits—self-esteem, generalized self-efficacy, locus of control, and emotional stability - with job satisfaction and job performance: A meta-analysis. Journal of applied Psychology, 86(1), 80.

Jung, J., and Kim, Y. 2012. Causes of newspaper firm employee burnout in Korea and its impact on organizational commitment and turnover intention. The International Journal of Human Resource Management, 23(17), 3636-3651.

Karatepe, O. M. 2013. High-performance work practices, work social support and their effects on job embeddedness and turnover intentions. International Journal of Contemporary Hospitality Management, 25(6), 903-921.

Karatepe, O. M. 2016. Does job embeddedness mediate the effects of coworker and family support on creative performance? An empirical study in the hotel industry. Journal of Human Resources in Hospitality and Tourism, 15(2), 119-132.

Karatepe, O. M., and Nkendong, R. A. 2014. The relationship between customer-related social stressors and job outcomes: the mediating role of emotional exhaustion. Ekonomska istra:̌ivanja, 27(1), 414-426.

Kensbock, S., Bailey, J., Jennings, G., and Patiar, A. 2015. Sexual Harassment of Women Working as Room Attendants within 5-Star Hotels. Gender, Work and Organization, 22(1), 36-50. 
Kim, M., and Beehr, T. A. 2017. Self-efficacy and psychological ownership mediate the effects of empowering leadership on both good and bad employee behaviors. Journal of Leadership and Organizational Studies, 24(4), 466-478.

Kirk, B. A., Schutte, N. S., and Hine, D. W. 2011. The effect of an expressive-writing intervention for employees on emotional self-efficacy, emotional intelligence, affect, and workplace incivility. Journal of Applied Social Psychology, 41(1), 179-195.

Kline, R. B. 1998. Software review: Software programs for structural equation modeling: Amos, EQS, and LISREL. Journal of psychoeducational assessment, 16(4), 343-364.

Laschinger, H. K. S. 2008. Effect of empowerment on professional practice environments, work satisfaction, and patient care quality: Further testing the nursing worklife model. Journal of nursing care quality, 23(4), 322-330.

Lee, J. J., and Ok, C. M. 2014. Understanding hotel employees' service sabotage: Emotional labor perspective based on conservation of resources theory. International Journal of Hospitality Management, 36, 176-187.

Lim, S., and Lee, A. 2011. Work and nonwork outcomes of workplace incivility: Does family support help?. Journal of Occupational Health Psychology, 16(1), 95.

Lim, S., Cortina, L. M., and Magley, V. J. 2008. Personal and workgroup incivility: impact on work and health outcomes. Journal of Applied Psychology, 93(1), 95.

Lim, S., Ilies, R., Koopman, J., Christoforou, P., and Arvey, R. D. 2016 Emotional mechanisms linking incivility at work to aggression and withdrawal at home: an experience-sampling study. Journal of Management, 0149206316654544.

Mackey, J. D., Bishoff, J. D., Daniels, S. R., Hochwarter, W. A., and Ferris, G. R. 2017. Incivility's Relationship with Workplace Outcomes: Enactment as a Boundary Condition in Two Samples. Journal of Business Ethics, 1-16.

Maslach, C., and Jackson, S. E. 1996. Leiter MP Maslach Burnout Inventory Manual. Palo Alto.

Mikkelsen, E. G. E., and Einarsen, S. 2002. Basic assumptions and symptoms of post-traumatic stress among victims of bullying at work. European journal of work and organizational psycholo$g y, 11(1), 87-111$.

Mitchell, T. R., Holtom, B. C., Lee, T. W., Sablynski, C. J., and Erez, M. 2001. Why people stay: Using job embeddedness to predict voluntary turnover. I, 44(6), 1102-1121.

Nelson, J., Nichols, T., and Wahl, J. 2017. The Cascading Effect of Civility on Outcomes of Clarity, Job Satisfaction and Caring for Patients. Interdisciplinary Journal of Partnership Studies, 4(2), 6.

Paek, S., Schuckert, M., Kim, T. T., and Lee, G. 2015. Why is hospitality employees' psychological capital important? The effects of psychological capital on work engagement and employee morale. International journal of hospitality management, 50, 9-26. 
Perrewé, P. L., Zellars, K. L., Ferris, G. R., Rossi, A. M., Kacmar, C. J., and Ralston, D. A. 2004. Neutralizing job stressors: Political skill as an antidote to the dysfunctional consequences of role conflict. Academy of Management Journal, 47(1), 141-152.

Pizam, A. 2008. Depression among foodservice employees.

Podsakoff, P. M., MacKenzie, S. B., Lee, J. Y., and Podsakoff, N. P. 2003. Common method biases in behavioral research: a critical review of the literature and recommended remedies. Journal of applied psychology, 88(5), 879.

Porath, C. L., and Pearson, C. M. 2010. The cost of bad behavior. Organizational Dynamics, 39(1), 64-71.

Porath, C. L., and Pearson, C. M. 2012. Emotional and behavioral responses to workplace incivility and the impact of hierarchical status. Journal of Applied Social Psychology, 42(S1).

Reio Jr, T. G., and Sanders-Reio, J. 2011. Thinking about workplace engagement: does supervisor and coworker incivility really matter?. Advances in Developing Human Resources, 13(4), 462-478.

Roberts, S. J., Scherer, L. L., and Bowyer, C. J. 2011. Job stress and incivility: What role does psychological capital play?. Journal of Leadership and Organizational Studies, 18(4), 449-458.

Robinson, S. L., and Bennett, R. J. 1995. A typology of deviant workplace behaviors: A multidimensional scaling study. Academy of management journal, 38(2), 555-572.

Sakurai, K., and Jex, S. M. 2012. Coworker incivility and incivility targets' work effort and counterproductive work behaviors: The moderating role of supervisor social support. Journal of Occupational Health Psychology, 17(2), 150.

Salanova, M., Lorente, L., Chambel, M. J., and Martínez, I. M. 2011. Linking transformational leadership to nurses' extra-role performance: the mediating role of self-efficacy and work engagement. Journal of Advanced Nursing, 67(10), 2256-2266.

Schilpzand, P., De Pater, I. E., and Erez, A. 2016. Workplace incivility: A review of the literature and agenda for future research. Journal of Organizational Behavior, 37(S1).

Schreurs, B., Van Emmerik, H., Notelaers, G., and De Witte, H. 2010. Job insecurity and employee health: The buffering potential of job control and job self-efficacy. Work and Stress, 24(1), 56-72.

Scott, K.L., Restubog, S.L. and Zagenczyk, T.J. 2013. "A social exchange-based model of the antecedents of workplace exclusion", Journal of Applied Psychology, 98, 37-48.

Semmer, N. K. 2003. Individual differences, work stress and health. Handbook of work and health psychology, 2, 83-120.

Shao, R., and Skarlicki, D. P. 2014. Service employees' reactions to mistreatment by customers: A comparison between North America and East Asia. Personnel Psychology, 67(1), 23-59.

Sharma, N., and Singh, V. K. 2016. Effect of workplace incivility on job satisfaction and turn- 
over intentions in India. South Asian Journal of Global Business Research, 5(2), 234-249.

Siu, O. L., Lu, C. Q., and Spector, P. E. 2007. Employees' wellbeing in Greater China: the direct and moderating effects of general self-efficacy. Applied psychology, 56(2), 288-301.

Sliter, M., Sliter, K., and Jex, S. 2012. The employee as a punching bag: The effect of multiple sources of incivility on employee withdrawal behavior and sales performance. Journal of Organizational Behavior, 33(1), 121-139.

Smidt, O., De Beer, L. T., Brink, L., and Leiter, M. P. 2016. The validation of a workplace incivility scale within the South African banking industry. SA Journal of Industrial Psychology, 42(1), $1-12$.

Taylor, S. G., and Kluemper, D. H. 2012. Linking perceptions of role stress and incivility to workplace aggression: the moderating role of personality. Journal of occupational health psychology, 17(3), 316.

Treadway, D. C., Hochwarter, W. A., Kacmar, C. J., and Ferris, G. R. 2005. Political will, political skill, and political behavior. Journal of organizational behavior, 26(3), 229-245.

Trougakos, J. P., Hideg, I., Cheng, B. H., and Beal, D. J. 2014. Lunch breaks unpacked: The role of autonomy as a moderator of recovery during lunch. Academy of Management Journal, 57(2), 405-421.

van Dinther, M., Dochy, F., and Segers, M. 2011. Factors affecting students' self-efficacy in higher education. Educational research review, 6(2), 95-108.

Wilkerson, J. M., Evans, W. R., and Davis, W. D. 2008. A test of coworkers' influence on organizational cynicism, badmouthing, and organizational citizenship behavior. Journal of Applied Social Psychology, 38(9), 2273-2292.

Wilson, N. L., and Holmvall, C. M. 2013. The development and validation of the Incivility from Customers Scale. Journal of occupational health psychology, 18(3), 310.

Wright, T. A., and Cropanzano, R. 1998. Emotional exhaustion as a predictor of job performance and voluntary turnover. Journal of applied psychology, 83(3), 486.

Yeung, A., and Griffin, B. 2008. Workplace incivility: Does it matter in Asia?. People and Strate$g y, 31(3), 14$.

YİİK, Ş., and ÖREN, D. 2014. A Study to Determine the Relationship between Job Satisfaction and Tendencies of Employees of 5 Star Hotels Operating 12 Months in Belek. Journal of Alanya Faculty of Business/Alanya Isletme Fakültesi Dergisi, 6(2). 